\title{
THE ROLE OF MYOCARDIAL PERFUSION IMAGING IN PATIENTS WITH DIABETES MELLITUS
}

Raluca Mititelu, Cătălin Mazilu, Adina Mazilu, Silviu Stanciu

Central Universitary Emergency Military Hospital, Bucharest

\section{Rezumat}

Diabetul zaharat reprezintă o patologie complexă, cu incidența în creștere și care asociază un risc crescut de boală coronariană. Scintigrafia miocardică de perfuzie este o metodă importantă de evaluare a pacienților cu boală coronariană, având o valoare prognostică foarte ridicată.

Obiective. Scopul acestui studiu a fost aprecierea rolului scintigrafiei miocardice de perfuzie în evaluarea pacienților cu diabet zaharat și boală coronariană ischemică.

Metodă. Am efectuat un studiu retrospectiv pe un lot de 128 de pacienți care au efectuat scintigrafie miocardică de perfuzie la efort și la repaus și la care a fost disponibilă evaluarea coronarografică. Pacienților li s-a efectuat scintigrafie miocardică SPECT de perfuzie la efort și la repaus (protocol de o zi sau de două zile). Radiofarmaceuticele utilizate au fost 99m-Tc-MIBI sau tetrofosmin. Pentru achiziție s-a utilizat un protocol SPECT gated, sincronizat cu electrocardiograma, utilizând o gamma cameră dual-head. Lotul de pacienți a fost împărțit în 4 grupe, pe baza prezenței sau nu a diabetului zaharat și a leziunilor coronariene semnificative.

Rezultate. În grupul pacienților cu afectare coronariană semnificativă și cu diagnostic de diabet zaharat numărul defectelor de perfuzie evidențiate scintigrafic a fost mai mare, cu severitate mai crescută și asociind în mai mare măsură disfuncție sistolică. Rezultatele noastre susțin faptul că extinderea și severitatea defectelor de perfuzie sunt mai mari la pacienții cu diabet zaharat față de pacienții non-diabetici.

Concluzii. Scintigrafia miocardică de perfuzie este o metodă fezabilă pentru diagnosticul și evaluarea bolii coronariene la pacienții cu diabet zaharat.

Cuvinte cheie: scintigrafie miocardică de perfuzie, diabet zaharat, boală coronariană ischemică.

\footnotetext{
Abstract

Diabetes mellitus is a complex pathology with increasing incidence, associated with an increased risk of coronary heart disease. Myocardial perfusion imaging (MPI) is an important diagnostic tool for the evaluation of coronary artery disease (CAD), with a high prognostic value.
} 


\section{INTERNAL} MEDICINE Original Papers

Objective. The aim of this study was to evaluate the role of stress-rest MPI in the assessment of patients with DM and suspected or confirmed CAD.

Method. We performed a retrospective analysis of 128 patients who underwent stress-rest MPI in our department, all of them with coronary angiography (CA) available. All patients underwent stress rest myocardial perfusion SPECT using a 1-day or 2-day protocol. The radiopharmaceuticals used were $99 \mathrm{~m}-\mathrm{TC}-\mathrm{MIBI}$ or tetrofosmin. The study was performed with a gated protocol SPECT, synchronous with the ECG, using a dual-head gamma camera. Patients were divided in 4 subgroups based on the presence of DM and of significant CA changes.

Results. In the group of patients with significant coronary disease on CA and previously diagnosed DM, number of perfusion defects on the stress-rest MPI were higher and also the presence of systolic disfunction and the severity of defects. Our results support the idea that the severity and extent of myocardial perfusion defects are greater in diabetic patients than in non-diabetic patients.

Conclusions. We can consider myocardial perfusion SPECT with 99mTc-labeled agents as a feasible method for the diagnosis and evaluation of CAD and for the management of diabetic patients.

Keywords: myocardial perfusion imaging, diabetes mellitus, coronary artery disease.

Diabetes mellitus is a complex pathology with increasing incidence, associated with an increased risk of coronary heart disease that is almost twice as high as in the general population $^{(1)}$. Approximately $2 / 3$ of deaths in patients with DM are due to cardiovascular disease $^{(2)}$, with coronary artery disease (CAD) being the most common cause of death in these patients ${ }^{(3)}$.

In recent years, the prevalence of type 2 diabetes has increased in both developed and developing countries worldwide. This is due to the combined effect of several factors: aging population, increasing obesity and inactivity, increasing life expectancy (attributed to improved health management). It is predicted that by 2025 there will be 380 million people with type 2 diabetes and 418 million people with impaired glucose tolerance ${ }^{(4)}$.

Myocardial perfusion imaging (MPI) is an important diagnostic tool for the evaluation of coronary artery disease. It is a nuclear medicine technique that allows the 
assessment of stress and rest perfusion in the cells of the myocardial wall.

MPI is a widely used imaging modality for the management of heart disease worldwide. There are many studies showing an important diagnostic and prognostic value of $\mathrm{MPI}^{(5-7)}$, with a normal SPECT MPI being an indicator of a very good prognosis, with an annual rate of less than $1 \%$ cardiac events ${ }^{(8,9)}$. However, it is known that the prognostic value of MPI in DM patients is different from that in non-diabetic patients. In DM patients, a normal MPI examination is associated with a $1.6 \%$ risk of serious cardiac events 1 year after the examination (versus less than $1 \%$ in nondiabetic patients ${ }^{(10)}$. In addition, the survival rate without serious cardiac events is lower in diabetic than in nondiabetic patients ${ }^{(11,12)}$.

\section{Objective}

The aim of this study was to evaluate the role of stress-rest $\mathrm{MPI}$ in the assessment of patients with DM and suspected or confirmed CAD.

\section{Methods}

We performed a retrospective analysis of 128 patients who underwent stress-rest MPI in our department. Of the patients, 61 were female, 67 were male, the mean age was 58 years, 57 of them had previously diagnosed DM, and 71 were non-diabetic. All patients underwent stress rest myocardial perfusion SPECT using a 1-day or 2-day protocol and all had coronary angiography (CA) available.

The radiopharmaceuticals used were $99 \mathrm{~m}$-TcMIBI or tetrofosmin. The study was performed with a gated protocol SPECT, synchronous with the ECG, using a dual-head gamma camera.

\section{Results}

On the MPI, perfusion defects were classified as "fixed" and "reversible." "Fixed" defects were defined as unchanged at rest and stress, whereas "reversible" defects were defined as new or more severe defects on stress examination compared with the rest study. We considered the number of segments affected and the degree of hypoperfusion. The kinetic data were useful to assess the function of LV and to distinguish some fixed defects from artifacts. Coronary lesions detected on coronarography were classified as "significant"- > 50\% and not significant.

We divided patients into 4 subgroups based on the presence of DM and of CA changes: Group A - DM patients with significant coronary lesions at CA - 33 (57.89\%); Group B- diabetics with non-significant coronary lesions at CA - 24 (42.11\%); Group C- nondiabetics, significant coronary lesions at CA 32 (45.07\%); Group D- non-diabetics, nonsignificant coronary lesions at CA - 39 (54.93\%). MPI showed significant perfusion defects in 31 out of 33 patients in group A (93.9\%), 3/24 patients in group B (12.5\%), $29 / 32$ patients in group C $(90.6 \%), 3 / 39$ patients from group $D(7.69 \%)$. Irreversible defects were seen in 27 patients in group $A$ $(81 \%)$ and 21 in group C (65\%). No patient in groups B and D had irreversible defects (groups with non-significant coronary lesions). A reduction in LVEF $<50 \%$ was noted in 19 patients in group $A(57 \%)$ and in 11 in group C (34.3\%). The results are summarized in Table 1.

\section{Discussions}

DM is a major cause of premature mortality worldwide, which is widely underestimated because only a minority of people with 
diabetes die from a cause exclusively related to the disease. The global excess mortality attributable to adult diabetes was estimated at 3.96 million deaths in $2010^{(13)}$.

The prevalence of silent myocardial ischemia diagnosed by MPI in DM patients shows wide variability in different published papers. Observational studies published 10 or more years ago at that time reported a prevalence ranging from $16 \%$ to $59 \%$, with approximately $20 \%$ of patients having a high-risk perfusion pattern $^{(14,15)}$.

More recently, the DIAD (Detection of Ischemia in Asymptomatic Diabetics) study - a prospective study involving truly asymptomatic patients - reported a lower prevalence of perfusion defects and functional abnormalities of LV - $22 \%{ }^{(16)}$. According to some authors, this percentage may represent the true prevalence of asymptomatic ischemia in DM patients ${ }^{(17)}$.

A recent analysis included 1,354 asymptomatic patients, 302 of whom had DM; all underwent MPI with exercise testing. The study showed a lower prevalence of myocardial ischemia (7.2\%) or ischemia with important prognostic value $(4.4 \%)$ in the total patients. On the other hand, the prevalence of asymptomatic ischemia was significantly higher in patients with DM compared with patients without DM $(12.5 \% \text { vs. } 5.6 \%)^{(18)}$. In our study, significant coronary lesions were detected in a higher number of patients with
DM and suspected CAD (57,89\% vs. $45,07 \%)$. In patients with significant coronary lesions, the number of patients with perfusion defects detected by MPI was comparable, but the severity of lesions tended to be higher in diabetics than in non-diabetics in terms of the number of myocardial segments affected and the degree of hypoperfusion.

The number of irreversible lesions was higher in diabetics ( $81 \%$ versus $65 \%$ ). The diabetic group also had a higher percentage of patients with perfusion defects and nonsignificant coronary lesions ( $12,5 \%$ vs. $7,69 \%$ in non-diabetics) - Figure 1. Figure 2 and Figure 3 show images obtained by stress-rest MPI in two of our patients with DM and suspected CAD at clinical presentation. Note the severity and extent of the defects in patients with not previously known CAD.

This is another important issue in these patients - the long-term evolution of ischemic heart disease and the presentation of a severe form, usually due to the absence or low number of symptoms associated with heart disease. This finding is also supported by other authors and should represent a consistent argument for systematic cardiac evaluation in all patients with $\mathrm{DM}^{(16)}$.

\section{Conclusions}

Myocardial perfusion SPECT shows a greater percentage of irreversible defects and a 


\begin{tabular}{|l|l|l|l|l|}
\hline & \multicolumn{2}{|l|}{ GROUP A and B (DM+) } & \multicolumn{2}{l|}{ GROUP C and D (DM-) } \\
\hline & $\begin{array}{l}\text { Group A } \\
\text { Cx+ DM+ }\end{array}$ & $\begin{array}{l}\text { Group B } \\
\text { Cx- DM+ }\end{array}$ & $\begin{array}{l}\text { Group C } \\
\text { Cx+ DM- }\end{array}$ & $\begin{array}{l}\text { Group D } \\
\text { Cx- DM- }\end{array}$ \\
\hline Patients (\%) & $\begin{array}{l}33 / 57 \\
(57.89 \%)\end{array}$ & $\begin{array}{l}24 / 57 \\
(42,10 \%)\end{array}$ & $\begin{array}{l}32 / 71 \\
(45.07 \%)\end{array}$ & $\begin{array}{l}39 / 71 \\
(54.92 \%)\end{array}$ \\
\hline $\begin{array}{l}\text { Reversible } \\
\text { defects }\end{array}$ & $31 / 33$ & $3 / 24$ & $29 / 32$ & $3 / 39$ \\
$(93.9 \%)$ & $(12.5 \%)$ & $(90.6 \%)$ & $(7.69 \%)$ \\
\hline $\begin{array}{l}\text { Irreversible } \\
\text { Defects }\end{array}$ & $27 / 33$ & 0 & $\begin{array}{l}21 / 32 \\
(65 \%)\end{array}$ & 0 \\
\hline $\begin{array}{l}\text { Low LVEF } \\
(<50 \%)\end{array}$ & $(81 \%)$ & 0 & $\begin{array}{l}11 / 32 \\
(34.3 \%)\end{array}$ & 0 \\
\hline
\end{tabular}

Table 1. Presence of MPI changes in all groups of patients

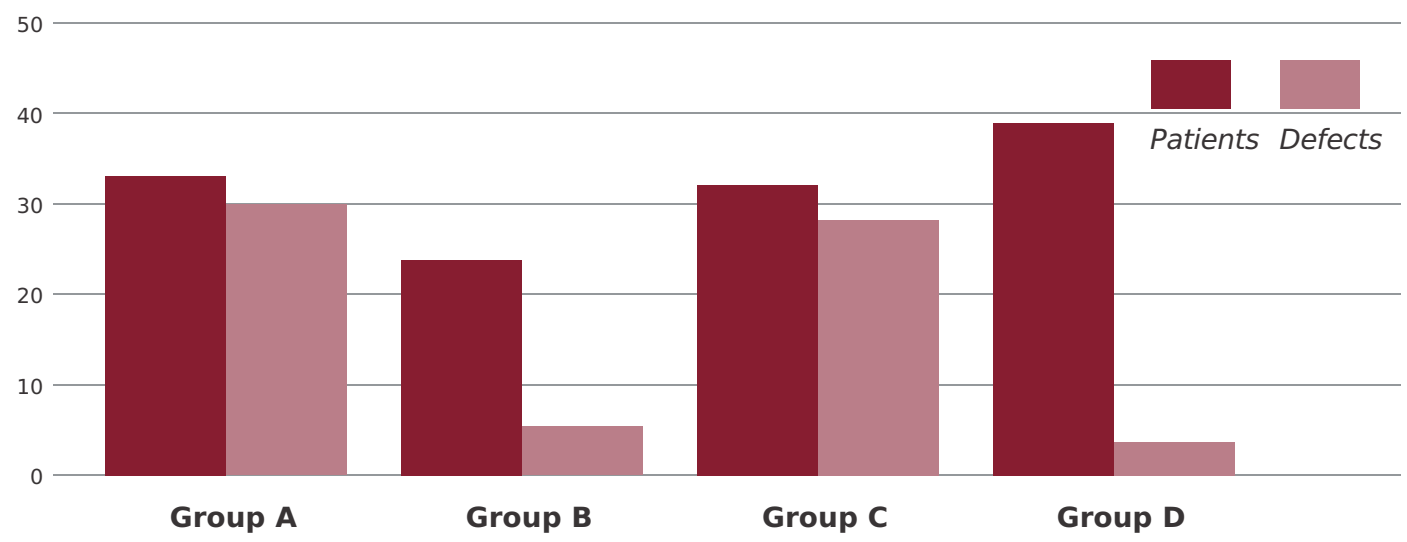

Figure 1. No of patients and percentage of defects in groups $A$ - D
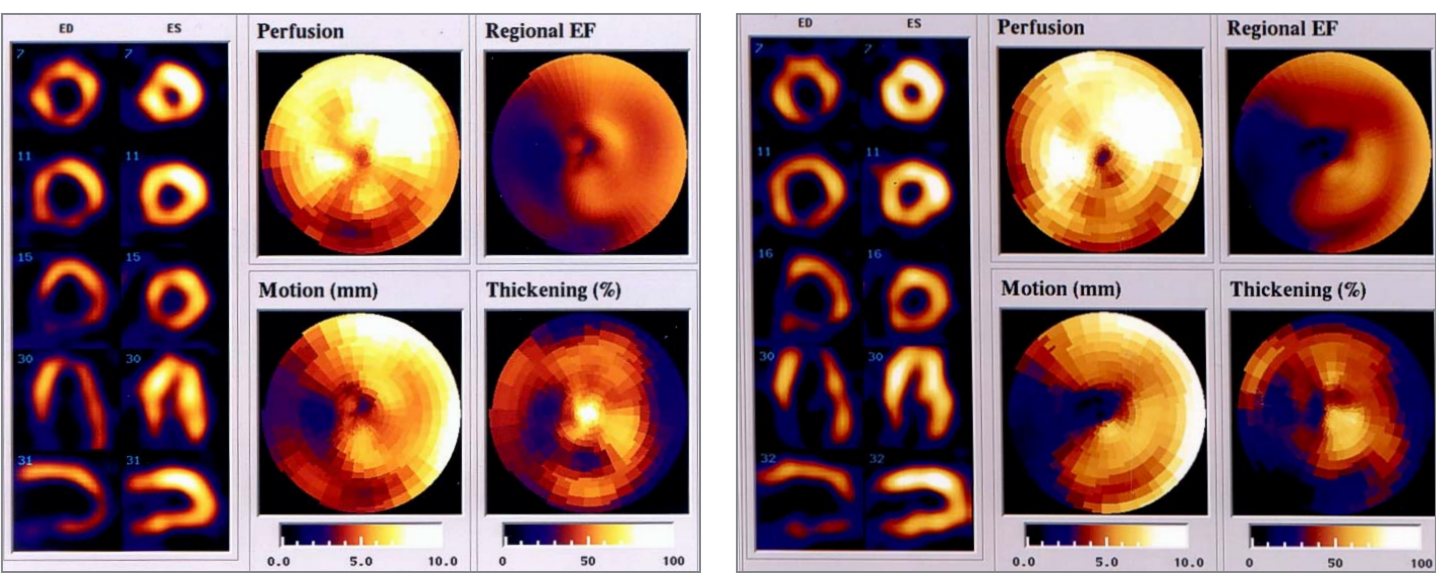

Figure 2. $M, 57 y$, retrosternal pain, DM (7 $y$ of treatment for DM). SPECT-gated in stress and rest partial reversible defect in inferior wall of LV; hypoperfusion partially reversible in antero-septal wall; we have noted good perfusion of the septum but with hypomotility and absence of systolic thickening (stunned myocardium?); 


\section{INTERNAL MEDICINE} Original Papers
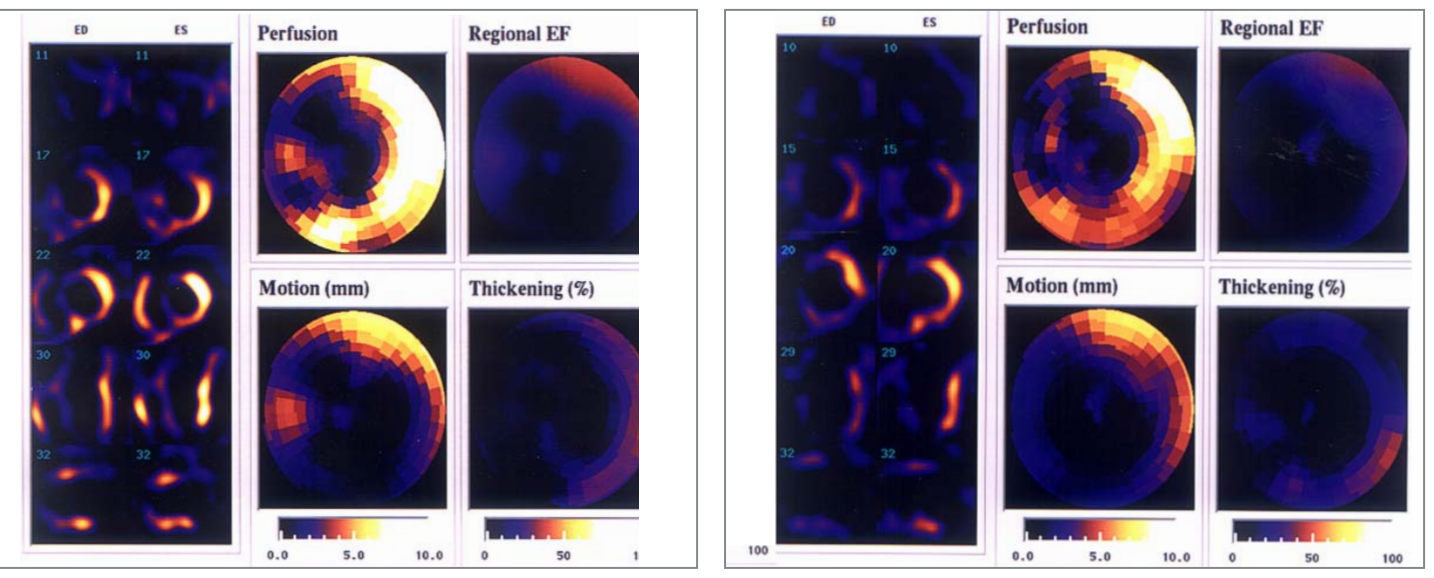

Figure 3. M, 63 y, DM, retrosternal pain. SPECT-gated in stress and rest - large, irreversible defect which occur in almost entire territory of $L A D$; large area of moderate hypoperfusion almost entirely reversible in the posterior wall; absence of motility in inferior wall (stunning?); lowering of regional and global LVEF; low global motility and systolic thickening

higher prevalence of stress-induced LVEF impairment in CAD diabetic patients. Our results support the idea that the severity and extent of myocardial perfusion defects are greater in diabetic patients than in nondiabetic patients.

We can consider myocardial perfusion SPECT with $99 \mathrm{mTc}$-labeled agents as a feasible method for the diagnosis and evaluation of CAD and for the management of diabetic patients.

\section{References}

1. N. Sarwar, P. Gao, S.R. Seshasai, et al. Diabetes mellitus, fasting blood glucose concentration, and risk of vascular disease: a collaborative meta-analysis of 102 prospective studies Lancet, 375 (2010), pp. 22152222

2. K. Gu, C.C. Cowie, M.I. Harris Mortality in adults with and without diabetes in a national cohort of the US population, 19711993 Diabetes Care, 21 (1998), pp. 11381145

3. Young LH, Wackers FJT, Chyun DA, et al. Cardiac Outcomes After Screening for Asymptomatic Coronary Artery Disease in Patients With Type 2 Diabetes: The DIAD Study: A Randomized Controlled Trial. JAMA. 2009;301(15):15471555. doi:10.1001/jama.2009.476

4. van Dieren S et al, The global burden of diabetes and its complications: an emerging pandemic. Eur J Cardiovasc Prev Rehabil. 2010 May;17 Suppl 1:S3-8. doi: 10.1097/01.hjr.0000368191.86614.5a

5. Cantoni, V., Green, R., Acampa, W. et al. Long-term prognostic value of stress myocardial perfusion imaging 
and coronary computed tomography angiography: $A$ meta-analysis. J. Nucl. Cardiol. 23, 185197 (2016). https://doi.org/10.1007/s12350-015-0349-3

6. Hachamovitch R., Hayes S., Friedman J.D., et al. Determinants of risk and its temporal variation in patients with normal stress myocardial perfusion scans: What is the warranty period of a normal scan? Journal of the American College of Cardiology, 41 (8) (2003), pp. 1329-1340

7. Berman DS, Hachamovitch $R$, Kiat $H$, et al. Incremental value of prognostic testing in patients with known or suspected ischemic heart disease: a basis for optimal utilization of exercise technetium-99m sestamibi myocardial perfusion single-photon emission computed tomography. J Am Coll Cardiol. 1995; 26:639647

8. Iskandrian AS, Chae SC, Heo J et al, Independent and incremental prognostic value of exercise single-photon emission computed tomographic (SPECT) thallium imaging in coronary artery disease. J Am Coll Cardiol. 1993;22:665670

9. Hachamovitch $R$, Berman DS, Shaw LJ, et al. Incremental prognostic value of myocardial perfusion single photon emission computed tomography for the prediction of cardiac death: differential stratification for risk of cardiac death and myocardial infarction. Circulation. 1998;97:535543

10. W. Acampa, V. Cantoni, R. Green, et al. Prognostic value of normal stress myocardial perfusion imaging in diabetic patients: a meta-analysis J Nucl Cardiol, 21 (2014), pp. 893902

11. D.V. Anand, E. Lim, D. Hopkins, et al.Risk stratification in uncomplicated type 2 diabetes: prospective evaluation of the combined use of coronary artery calcium imaging and selective myocardial perfusion scintigraphy Eur Heart J, 27 (2006), pp. 713721 12. S. Giri, L.J. Shaw, D.R. Murthy, et al.Impact of diabetes on the risk stratification using stress single-photon emission computed tomography myocardial perfusion imaging in patients with symptoms suggestive of coronary artery disease Circulation, 105 (2002), pp. 3240 13. Roglic $G$ et al, Mortality attributable to diabetes: estimates for the year 2010 Diabetes Res Clin Pract. 2010 Jan;87(1):15-9. doi: 10.1016/j. diabres.2009. 10.006. Epub 2009 Nov 14

14. Miller TD, Rajagopalan N, Hodge DO, Frye RL, Gibbons RJ. Yield of stress single-photon emission computed tomography in asymptomatic patients with diabetes. Am HeartJ 2004;147:8906.

15. Rajagopalan N, Miller TD, Hodge DO, Frye RL, Gibbons RJ. Identifying high-risk asymptomatic diabetic patients who are candidates for screening stress singlephoton emission computed tomography imaging. J Am Coll Cardiol 2005;45:439

16. Wackers FJ, Young LH, Inzucchi SE, et al., Detection of Ischemia in Asymptomatic Diabetics Investigators. Detection of silent myocardial ischemia in asymptomatic diabetic subjects: the DIAD study. Diabetes Care 2004;27:195461

17. MJ Budoff et al Noninvasive Cardiovascular Risk Assessment of the Asymptomatic Diabetic Patient : The Imaging Council of the American College of Cardiology JACC: Cardiovascular Imaging, Volume 9, Issue 3, March 2016, Page 335

18. Malhotra S, Sharma R, Kliner DE, Follansbee WP, Soman P. Relationship between silent myocardial ischemia and coronary artery disease risk factors. J NuCl Cardiol 2013;20:7318 